Article received on 14 October 2013

Article accepted on 30 November 2013

UDC

\title{
INCEPTION OF WAGNER'S DOCTRINE OF REGENERATION PRIOR TO THE REVOLUTION 1848-1849'
}

\author{
Dragana Jeremić Molnar* \\ University of Arts in Belgrade \\ Faculty of Music \\ Department of Musicology
}

\begin{abstract}
The predominant opinion in contemporary science is that Richard Wagner began formulating his doctrine of regeneration in the 1860 s, with a subsequent elaboration in the so-called regeneration writings, creating a sort of theoretical platform for working on Parsifal, a festival play for the consecration of the stage. Wagner's written legacy, however, shows that he had been thinking about regeneration ever since the 1840 s, as well as that he used the term in a broad range of meanings - especially considering that he used that word of the French origin as the synonym for the German word Wiedergeburt. This paper focuses on three instances where he referred to regeneration in the fifth decade of the $19^{\text {th }}$ century: a letter from 1843 , a text "How do republican aspirations stand in relation to the monarchy?", and a paper Art and Revolution. In 1843, Wagner had only vague ideas about regeneration in art; five years later, while the city of Dresden was eagerly awaiting the revolutionary wave from France, it was the rebirth of human society that he had in mind; after the collapse of the revolution, realizing his limitations and dispelling illusions about its success, he established a correlation - never to be dismissed - between regeneration and art; i.e. he fancied that the regeneration of the being of a nation's members could be achieved by exposing them to the effects of a special, true art.
\end{abstract}

Key words: Wagner, regeneration, rebirth, revolution, France, Germany

Wagner's doctrine of regeneration has engaged researchers long after his death. Since this was his central subject in the late (so-called philosophical or

\footnotetext{
* The author contact addres: admolnar@sbb.rs

1 The paper is the result of research conducted within Project No. 177019, carried out at the Department of Musicology of the Faculty of Music in Belgrade, and funded by the Ministry of Science of the Republic of Serbia. I extend my gratitude to Professor Aleksandar Molnar for recommending the relevant sources indispensable for writing the sections devoted to the perception of the political situation in France.
} 
regeneration) writings, it is no wonder that it attracted the attention of those who had an opportunity to meet him personally and to gain a direct insight into his views. The Wagnerians themselves have often claimed that the doctrine of regeneration is a sort of key to the easiest interpretation of all of Wagner's main ideas (often completely contradictory to one another) - not only philosophical but political ones, too. Thus, for instance, in the book Richard Wagner (1985), the seminal work for the development of the Bayreuth Circle ideology, Houston Stewart Chamberlain noted:

Our enquiry into Wagner's political and philosophical thoughts was much impeded by the circumstance that they only occurred as accessory parts of expositions in other of thought. We had to search for them amongst a mass of writings and letters, and the fact that his views were nowhere systematically laid down made it difficult to define them sharply. The doctrine of regeneration [Regenerationslehre] on the other hand forms the main subject of a whole series of essays, and is formulated so clearly that it would seem as if we were standing upon terra firma, and that it must be easy to follow a course of thought worked out so lucidly and in such detail, and to reproduce it to ourselves on a diminished scale. ${ }^{2}$

The interest in Wagner's doctrine dwindled appreciably after 1945, and for a very tangible reason - it was too closely intertwined with anti-Semitism. Prior to that, the doctrine of regeneration was studied mostly by rightist intellectuals, who could hardly wait to bring Wagner's anti-Semitic ideas to the fore. Those who dealt with Wagner after the war mostly strived to avoid the problematization of his doctrine of regeneration as something allegedly irrelevant in essence. For all the researchers who wanted to find a 'healthy' Wagner, not imbued with anti-Semitism, the doctrine of regeneration was a great obstacle; to those, on the other hand, who wanted to expose Wagner for an anti-Semite, it looked like an esoteric façade and unnecessary ballast. Today, a balanced dealing with Wagner's doctrine of regeneration entails avoiding both extremes: either by proclaiming it to be a magic formula which can gloss over all the contradictions in Wagner's oeuvre (giving it a universal anti-Semitic orientation), or cheapening it to the level of a marginal discourse with great philosophical pretentions and feeble substance of meaning.

'Regeneration writings' (Regenerationsschriften) is the unified label most often used for Wagner's shorter texts which he wrote late in his life and published in the Bayreuth Blätter. ${ }^{3}$ These texts, in which he dealt with joining

\footnotetext{
2 Houston Stewart Chamberlain, Richard Wagner, trans. Ainslie Hight, J. M. Dent \& Co., London, 1900, 163-164.

3 The first of Wagner's regeneration writings was "Modern" ("Moderne", 1878), and the last was "Heroism and Christianity" ("Heldentum und Christentum", 1881).
} 
art, religion and philosophy, were the pinnacle of his efforts at interpreting, elaborating and personally adjusting the philosophy of Arthur Schopenhauer (which he had discovered in 1854). ${ }^{4}$ Therefore, an opinion was formed that Wagner problematized regeneration in his old age, as a sort of accompanying/complementary subject while working on Parsifal, and without any other foothold in his oeuvre to date, apart from those stemming from the reception of Schopenhauer's philosophy. The researchers of Wagner's work included those who found his first regeneration writings among his texts written in the 1860 s, when he became disillusioned about the power of a revolution and when he strived to rehabilitate himself and his art in the higher circles of Germany, caught up in the euphoria on the eve of the creation of the Second Reich. Thus, Carl Friedrich Glasenapp, who in 1904 published a six-volume biography of Wagner, is the originator of a widespread misconception that "Der Begriff der 'Regeneration' begegnet uns im literarischen Gedankenkreise Richard Wagners zuerst in der ebengenannten Schrift über 'deutsche Kunst und deutsche Politik" ["the notion of 'regeneration' in Wagner's thought is first encountered in the eponymous writing on 'German art and German politics'] ("Deutsche Kunst und deutsche Politik", 1867-1868), as well as that the meaning of the term was the liberation of Germany from "undeutschen Zivilisation durch eine Erneuerung und Wiedergeburt des deutschen Wesens" ["non-German civilization through the renewal and rebirth of the German essence"]. ${ }^{5}$ A detailed inspection of Wagner's written legacy shows that he thought about regeneration not only for the last sixteen years of his life, but for at least forty, and that he used the term in the broader range of meanings - especially considering that he employed that word of French origin as the synonym for the German word Wiedergeburt.

Wagner started using the words Wiedergeburt and Regeneration as early as in the 1840s. From 1841 to 1849 , he referred once to Regeneration, while he used Wiedergeburt six times, of which three times in a purely descriptive way. His words "Der Wiedergeburt der neueren Kunst bis zum Schluß des siebzehnten Jahrhunderts" ["the rebirth of the new art by the end of the seventeenth century"] from a text that, on $1^{\text {st }}$ December 1841, he sent from Paris to be published in Dresdener Abendzeitung, clearly show that the first appearance of the word Wie-

${ }^{4}$ Cf. Paul Lawrence Rose, Wagner, Race, and Revolution, Faber and Faber, London and Boston, 1992, 136; and Wolf-Daniel Hartwich, "Religion and art in Wagner's later years. The Relationship between aesthetics theology and anthropology in the 'regenerative writings"”, Wagner 21/1, 2000, 23.

5 Carl Friedrich Glasenapp, Das Leben Richard Wagners. Vol. VI, Breitkopf \& Härtel, Leipzig, 1905, 354. 
dergeburt had the meaning of renaissance. ${ }^{6}$ Wagner also equated Wiedergeburt with renaissance at one point in the text Art and Revolution (Die Kunst und die Revolution, 1849). ${ }^{7}$ The third, ideologically relevant reference to Wiedergeburt can be found in the text The Wibelungen. World-history as told in the saga (Die Wibelungen. Weltgeschichte aus der Sage, 1848), at the point where he described the Germanic mythological notion of "die irdische Wiedergeburt eines idealen Gottes" ["the earthly rebirth of an ideal God"]. ${ }^{8}$ The remaining four references to regeneration/rebirth - in a letter from 1843, in a revolutionary text "How do republican aspirations stand in relation to the monarchy?" ("Wie verhalten sich republikanische Bestrebungen dem Königtum gegenüber?”, 1848), and twice in the paper Art and Revolution - have a measurable ideological weight.

Wagner first mentioned Regeneration in a letter to Dr August Schmidt, the editor of the journal Allgemeine Wiener Musikzeitung, dated $14^{\text {th }}$ September 1843. In that letter he complained about the devastating reviews of Rienzi (which had its premiere in Dresden on $20^{\text {th }}$ October 1842) and putforward a "well-intended plea that, for the sake of regeneration [...] of our German opera [...], the debuts of German musicians be greeted in a friendlier fashion". ${ }^{9}$ In his first reference to regeneration, Wagner linked it with the critics' partiality, which means that he understood it quite simply, as the renewal of the quality of opera. The quoted excerpt is important for two reasons: because it shows that Wagner decided on the word Regeneration instead of Wiedergeburt, and because it reveals that he already considered Rienzi his personal contribution to the regeneration of German opera. Taking into account that Wagner moved to Dresden from Paris a year earlier, in 1842, we could assume that the implicit qualification of Rienzi as a contribution to the "regeneration of our German opera" was a reverberation of the way of thinking he brought to Germany from France. For while living in Paris, from 1839 to 1842, Wagner could indeed learn

\footnotetext{
${ }^{6}$ Richard Wagner, "Pariser Berichte für die Dresdener Abendzeitung. 8: Delaroche's Wandgemälde", in: Sämtliche Schriften und Dichtungen, 6324.

7 Richard Wagner, “Art and Revolution”, in: Richard Wagner's Prose Works, Vol. I: The Artwork of the Future, trans. William Ashton Ellis, Kegan Paul, Trench, Trübner and Co., London, 1892, 40.

${ }^{8}$ Richard Wagner, "Wibelungen. Weltgeschichte aus der Sage", in: Sämtliche Schriften und Dichtungen, 736

9 "So stelle ich meine herzlich gemeinte Bitte im Interesse der Regeneration unserer deutschen Opera dahin, fortan die Debüts deutscher Musiker freundlicher zu begrüßen". Richard Wagner, “An Dr. August Schmidt, Wien”, in: Sämtliche Schriften und Dichtungen, 8356.
} 
that underlying the French word régénération were multiple meanings shaped over the course of time, especially in the $18^{\text {th }}$ and the $19^{\text {th }}$ centuries.

As stated by Antoine de Baecque in the book The Body Politic: Corporeal Metaphor in Revolutionary France, 1770-1800 (Le Corps de l'Histoire: métaphores et politique /1770-1800/, 1993), in France "before 1730, regeneration was still used only in religious and medical vocabularies. [...] But, little by little, during the course of the last years of the ancien régime, regeneration came to designate rebirth in all its aspects - physical, moral, then quite specifically political". ${ }^{10}$ The perception of regeneration through religious categories was, at any rate, primary. The authors of theological treatises understood regeneration as baptism and resurrection (by the former, an individual becomes a child of God, entitled to life everlasting, while by the latter, they exercise that right), and sometimes they spoke even of putting an end to this ('degenerate') world and establishing the Kingdom of Heaven on earth. Therefore, it was theological interpretations of the biblical concept of regeneration that first opened a perspective on a rebirth of the world, which begins by the act of the transformation of an individual (through baptism).

In early- $18^{\text {th }}$-century France, the medical (or more precisely, biological) meaning of regeneration (as in 'regrowth of lost tissue') came into use. Due to the increasing number of the domains of its use, as well as the growing frequency of its appearance, regeneration also found its way into general dictionaries, such as Dictionnaire de l'Académie, which previously (e.g. in the 1696 edition) did not even register it. The 1740 and the 1762 editions of this dictionary explained not only the theological meaning of the word, but the medical too, and the 1798 edition, under the direct influence of the ongoing revolution, informed the readership about its moral and political meaning.

Albeit the most recent, the political meaning of regeneration has taken precedence over the other meanings since the very beginning of the French Revolution, and not later than 1792, the year of its radicalization. It synthesized the discourse of political degeneration ${ }^{11}$ with the religious (change of the entire

10 Antoine de Baecque, The Body Politic: Corporeal Metaphor in Revolutionary France, 1770-1800, trans. Charlotte Mandell, Stanford University Press, Stanford, 1993, 131.

11 The application of the concept of regeneration in the political domain was a sort of reaction to the concept of degeneration which was increasingly present in France during the last years of the Ancien Régime. This is well-illustrated by De Baecque's words: "At the end of the eighteenth century, when writers were denouncing at length the decline of the 'French Empire', it was precisely degeneration that occupied people's minds. By rhetorical effects, they induced an emotional response to a fundamentally pessimistic discourse, a hope in which restitution became the central figure. The 'regeneration of the kingdom' is a concept whose emergence was thus prepared by the massive use of a pre-established pessimistic 
world), medical (renewal of 'the body of the nation') and moral (reestablishment of virtues) components of regeneration. Regeneration thus became a synonym for the most ambitious goals of the Revolution. There was a propagation of claims - such as, "The Jacobins claimed to be the regenerators of the human race" - and new phrases - such as, "a regenerative Republic of the Universe" and "regenerative philosophy, destined to change the face of our societies" 12 - which were unthinkable before 1789. The revolutionaries referred to regeneration in order to attribute a greater significance to the Revolution. However, regeneration also found its place in the discourse of the counterrevolutionaries, who saw it as a brutal and violent tool that God employed to eradicate all the consequences of the previous degeneration and to prepare the world for the true regeneration, the one which would have nothing to do either with the Revolution or with its proclaimed goals, but only with the truest Christian doctrine. Such a perception of regeneration was hinted as early as in Letter to a friend, or philosophical and religious considerations on the French Revolution (Lettre à un ami, ou Considérations philosophiques et religieuses sur la révolution française, 1795) by Louis-Claude de Saint-Martin, ${ }^{13}$ and fully shaped in the paper Considerations on France (Considérations sur la France, 1796) by Joseph de Maistre. At one point in the paper, De Maistre summed up his views:

In short, the more one examines the apparently most active personages in the Revolution, the more one finds in them something passive and mechanical. We cannot repeat too often that men do not lead the Revolution: it is the Revolution that uses men. They are right when they say it goes all alone. This phrase means that never has the Divinity shown itself so clearly in any human event. If the vilest instruments are employed, punishment is for the sake of regeneration. ${ }^{14}$

De Maistre did not dispute the viewpoint that France, by the end of the Ancien Régime, had already become deeply degenerate and that the Revolution

discourse, typically characterizing the morale of the French court at the end of the reign of Louis XV”. Ibid., 134-135.

12 Ibid., 133-134.

${ }^{13}$ For Saint-Martin, regeneration was "a supernatural experience which is possible only to the immortal spirit" and Revolution was "the preparation of the Sabbatic way, and not the last reason was that it threw so many men, as it were, into the arms of God's will because all other protections, all other resources, had been taken from them". Arthur Edward Waite, The Unknown Philosopher: The Life of Louis Claude de Saint-Martin and the substance of his transcendental doctrine, P. Wellby, London, 1901, 203 and 355. Cf. Arthur McCalla, A Romantic Historiosophy: The Philosophy of History of Pierre-Simon Ballanche, Brill, Leiden, Boston and Köln, 1998, 292.

${ }_{14}$ Joseph de Maistre, Considerations on France, trans. Richard A. Lebrun, McGill-Queen's University Press, Montreal, 1974, 97. 
was necessary. But in his opinion, the Revolution should not haveestablished a Godless republic in imitation of the pagan Rome. Quite the contrary. It should have given God the opportunity to punish (whereas "punishment can have no other end than the removal of evil"); it should have admonished the people for all the sins that they had committed in the $18^{\text {th }}$ century, and then to have initiated a counterrevolution, which would be the true bearer of regeneration (in the $19^{\text {th }}$ century). "For Maistre, it [the Revolution] destroys, but will not know how to build a lasting order. The Revolution called for a regeneration, an act of faith that required not a rational but an intuitive certitude; whence the necessity of counterrevolution." 15 De Maistre canonized the conservative discourse which stylized the French Revolution into "a seminal event, a turning-point, a "chance for regeneration", and which would be embraced by the rightists in France (and elsewhere!). ${ }^{16}$ In other words, the French Revolution put an end to an age marked by sin, irreligion and revolution, and restored providence in history in order to prepare the ground for the real regeneration that was to follow in the $19^{\text {th }}$ century and which was to be understood as a sort of biblical prophecy coming true. ${ }^{17}$

The credit for the development of the conservative doctrine of regeneration in France should also be given to Pierre-Simon Ballanche, first and foremost for emphasizing the role of art in the process of regeneration. In his unfinished, ambitiously conceived five-volume work Essays on Social Palingenesis (Essais de palingénésie sociale) ${ }^{18}$, Ballanche took the word palingénésie (from the Greek

\footnotetext{
15 Jean-Louis Darcel, "The Apprentice Years of a Counter-Revolutionary: Joseph de Maistre in Lausanne, 1793-1797”, in: Richard Lebrun (ed.), Joseph de Maistre's Life, Thought, and Influence: Selected Studies, McGill-Queen's University Press, Ottawa, 2001, 37.

${ }_{16}$ Peter Davies, The extreme right in France, 1789 to the present: from de Maistre to Le Pen, Routledge, London and New York, 2002, 29.

${ }^{17}$ In that context, we should mention Thomas à Kempis's book The Imitation of Christ (De imitatione Christi, 1427), which started to exercise a strong influence in this period. "Edited five times and multiply reissued between 1800 and 1848, the mystical classic became a source of reflection on the historical consequences of sacrifice and on the Revolution as a victimal event": Carolina Armenteros, The French Idea of History: Joseph de Maistre and His Heirs, 1794-1854, Cornell University Press, New York, 2011, 257.

${ }_{18}$ Ballanche published the introductory volume, Prolégomènes, in 1827. In a note he revealed his ambition to write "the true history of the human race" and outlined the contents of each subsequent volume. However, he fully completed only the second volume, Orpheus (1829), dedicated to the history of Greece. The third volume, General formula of the history of all peoples applied to the history of the Roman people (Formule générale de l'histoire de tous les peuples appliquée à l'histoire du peuple romain), as well as the fourth, The city of expiations (La Ville des expiations), he kept rewriting until his death, but he never published them as books. He published the fragments which he considered satisfactory in journals between 1829 and 1834.
} 
word for regeneration, palingenesis) in the sense of a long historical process leading to recognition of all the key Catholic dogmas. Although he criticized the Saint-Simonists, whose enthusiasm for the French Revolution made them insist on quick changes, which they perceived outside the Catholic context, he was essentially very close to their doctrine about the avant-garde role of an artist in the process of regeneration. ${ }^{19}$ Together with the Saint-Simonist notion of avantgarde, it was his doctrine that would have a profound influence on "Liszt's cult of music of that time". ${ }^{20}$ Franz Liszt, who had been living in Paris since 1827, was the first composer who came in contact with the doctrine of palingénésie (regeneration) and started to relate it to music ${ }^{21}$ and art in general. Moreover, in the late 1830s Liszt thought about the regeneration of theatres for performing operas (i.e. 'dramatic music'). In an important essay-letter to Maurice Schlesinger, the editor of the Gazette musicale, which was published in the said journal in December 1839 under the title "On the Condition of Music in Italy" ("De l'état de la musique en Italie. M. le Directeur de la 'Gazette musicale", 1838), Liszt deemed it impossible that in Italy, by the performance of some Weber's or Mozart's opera, the taste for truly dramatic music would be reborn as if by a miracle [der Geschmack für wahrhaft dramatische Musik wie durch Zauberei wiedergeboren würde].Liszt believed that such an attempt would necessarily entail a great deal of resolution and willingness to listen to a myriad of absurd comments, and that after a long time only a small number of supporters would be won over. But when a man withthe taste and talent of an artist turned a deaf ear to the regeneration of theatre [Regeneration des Theaters], he exposed himself to the doom that befell church music and believed that a reform was possible because it finally and ultimately depended on the individual.Stepping forward like a man who did not only have religious feelings, but artistic ones too, and who became irritated when at the Divine Service and celebration of the holy mysteries one could only hear ridiculous and clumsy theatrical remi-

\footnotetext{
${ }^{19}$ For more about the doctrine cf. Dragana Jeremić Molnar and Aleksandar Molnar, Nestajanje uzvišenog i ovladavanje avangardnog u muzici moderne epohe. Knj. 2 [Disappearance of the Sublime and Preponderance of the Avant-Garde in the Music of the Modern Age. Vol. 2], Institut za filozofiju i društvenu teoriju i IP "Filip Višnjić", Belgrade, 2009, 10-15.

${ }^{20}$ McCalla, A Romantic Historiosophy, 360. Ballanche's influence on Liszt was mediated through the doctrine of "Palingénésie musicale" by Joseph d'Ortigue, who explained the history of Western music from Palestrina to Beethoven as the progress towards "the regenerated soil of Christianity". Cf. Benjamin Walton, "The First Biography: Joseph d'Ortigue on Franz Liszt at Age Twenty Three”, in: Christopher H. Gibbs and Dana Gooley (eds.), Franz Liszt and his world, Princeton University Press, Princeton and Oxford, 2006, 305.

${ }^{21}$ Inspired by Ballanche's concept of Palingénésie, Liszt composed the eponymous fantasy for piano in 1834 and the symphonic poem Orpheus in 1854.
} 
niscences [nur lächerliche und unschickliche Theaterreminiszenzen zu hören], Liszt complained about the degradation of the dramatic music performance in Italian (and not only Italian) operatic theatres. ${ }^{22}$

Liszt still did not refer to the regeneration of dramatic music itself (i.e. of opera as an artistic form). He obviously considered works by Mozart and Weber as perfectly worthy examples of true dramatic music and the real artistic counterparts of 'the Divine Service and celebration of the holy mysteries'. Actually, what bothered him were the conditions in which these works were performed. Therefore, he talked about the regeneration of theatre (i.e. of opera as an institution), which should have made it suitable for performing truly dramatic music. The desired regeneration, at any rate, should not have been confused with superficial theatrical reform carried out by a dedicated individual. It had to be ambitiously designed and universal - so that it would embody the spirit of the universal social palingenesis which Ballanche had in mind. In nuce, that was the assignment which, several decades later, was undertaken precisely by an 'individual' - admittedly, 'with the taste and talent of an artist' - Richard Wagner.

In 1843, when he wrote to Schmidt, Wagner still did not have in mind something as serious as the regeneration of theatre (he would begin advocating it during the revolution 1848-1849). On the other hand, in this period he was already thinking about the regeneration of German dramatic music itself, which Liszt (as a non-operatic composer) did not consider necessary. The two artists, whose viewpoints perhaps did not differ so much at the time, simply emphasized different dimensions of musical-dramatic art - the work, or the space in which the work is performed. Thus, it can be assumed that Wagner in France obviously formed some vague ideas about regeneration in the domain of art, but these were not mediated by Liszt, ${ }^{23}$ and he did not become aware of all their meanings and implications. As it turned out, a political trigger was necessary to initiate the brewing of these ideas and notions in Wagner.

\footnotetext{
${ }^{22}$ Cf. Franz Liszt, “An den Direktor der Gazette Musicale. Zum Stand der Musik in Italien”, in: Rainer Kleinertz (ed.), Sämtliche Schriften. Vol 1. Frühe Schriften, Breitkopf \& Härtel, Wiesbaden-Leipzig-Paris, 2000, 293.

${ }^{23}$ Wagner and Liszt had two brief encounters in Paris. They first met late in 1840, through the influence of the aforementioned Schlesinger. The following year, Liszt invited Wagner to one of his receptions. However, these encounters did not result in any sort of exchange of ideas. On the contrary: during the reception for the fashionable upper crust of Paris, which served to confirm Liszt's artistic charisma, Wagner's assuredness of the Manichaean image of the contemporary artistic world - split between true art, created by "social outcasts" (like him), and fashionable ostentatiousness of virtuosos (like Liszt) with the purpose of making money - could have only grown stronger, if anything. Cf. Sven Friedrich, Richard Wagner. Deutung und Wirkung, Königshausen \& Neumann, Würzburg, 2004, 98.
} 


\section{II}

In the text "How do republican aspirations stand in relation to the monarchy?" Wagner wrote about Wiedergeburt as a political issue, with much greater ambition than previously. This writing -which he published in a special supplement of the Dresdner Anzeiger newspaper on $14^{\text {th }}$ June 1848, and gave as a lecture to the Dresden revolutionaries gathered in the leftist organization Vaterlandsverein the following day - radiated with his enthusiasm for the revolution, which poured in waves from France to the German lands. Consequently, Wagner established a relation between Wiedergeburtand the current events, ascribing a revolutionary quality and character to the concept:

Sind wir nun in unseren republikanischen Bestrebungen soweit gelangt, auch diese wichtigste aller Fragen zum Glück und Wohlergehen der staatlichen Gesellschaft zu lösen, sind wir in die Rechte freier Menschenwürde vollständig eingetreten: werden wir nun am Ziele unseres thätigen Strebens angelangt sein? Nein! Nun soll es erst recht beginnen! Sind wir durch die gesetzkräftige Lösung der letzten Emanzipationsfrage zur vollkommenen Wiedergeburt der menschlichen Gesellschaft gelangt, geht aus ihr ein freies, allseitig zu voller Thätigkeit erzogenes neues Geschlecht hervor, so haben wir nun erst die Kräfte gewonnen, an die höchsten Aufgaben der Zivilisation zu schreiten, das ist: Bethätigung, Verbreitung derselben. Nun wollen wir in Schiffen über das Meer fahren, da und dort ein junges Deutschland gründen, es mit den Ergebnissen unseres Ringens und Strebens befruchten, die edelsten, gottähnlichsten Kinder zeugen und erziehen [...] vom Aufgang bis zum Niedergang soll die Sonne ein schönes, freies Deutschland sehen und an den Grenzen der Tochterlande soll, wie an denen des Mutterlandes, kein zertretenes unfreies Volk wohnen, die Strahlen deutscher Freiheit und deutscher Milde sollen den Kosaken und Franzosen, den Buschmann und Chinesen erwärmen und verklären. ${ }^{24}$

\footnotetext{
24 "If in our republican ambition we have come so far as to resolve this most important issue of happiness and prosperity of the state society, then we have stepped deep into the rights of free human dignity: but is this the final goal of our activity? No! It is only now that it should really begin! If by rightful solution to the last issue of emancipation we have reached a complete regeneration of human society, from which emanates a free human race, universally educated for complete activity, then only now have we gained power to undertake the highest tasks of civilization, that is: to exercise it and to spread it. Now we want to sail the seas in boats, to establish young Germany all over the world, to fertilize it by the results of our endeavours, to beget and nurture the most noble, God-like children [...]: from dawn till twilight, the sun should watch a beautiful and free Germany; trodden and enslaved people must not live on the borders of German settlements, or in the mother country; rays of German freedom and German gentleness should warm and illuminate Cossacks and the French, the Bushmen and the Chinese." Richard Wagner, "Wie verhalten sich republikanische Bestrebungen dem Königtum gegenüber?”, in: Richard Wagner, Sämtliche Schriften und Dichtungen, 6415-6416.
} 
A month earlier, in a similar mood, Wagner wrote "The Revolution" (1849), a political text in which he addressed the (obviously pagan) "goddess Revolution", ${ }^{25}$ perceived as "ever-rejuvenating, ever-fashioning Life" which destroys "the order of things" in order to enable the development of a free society. ${ }^{26}$ It is clear that revolution and "the regeneration of human society" were synonyms for Wagner in this period and that he used the terms as per his artistic fantasy. What was floating before his eyes was an image of a regenerated/revolutionized Germany, which would thereupon carry out regeneration in the whole world and bring to the most diverse nations its superior and autochthonous freedoms, originating from the Reformation. This phantasm, as Paul Lawrence Rose keenly observed, was very dangerous. For Wagner's faith in "a peculiarly German revolution in which the sacred German race was to blaze a path to freedom" and "emancipate the whole human race from a loveless and irrational way of life" could later, after the abatement of his revolutionary enthusiasm, potentially turn into a racist and anti-Semitic crusade. ${ }^{27}$

On $9^{\text {th }}$ July 1848 , euphoric because the revolution had started in February of the same year, Wagner travelled to Vienna, a city already engulfed by revolution, where he wanted to attend the revolutionary labours not only of the new Austria, but all of Germany. In the surreal atmosphere of a republican festivity that lasted for just one summer, Wagner let his artistic fantasy roam again, feeding it this time only with political subjects. Eduard Hanslick remembered that Wagner was ecstatic for an entire evening that two of them spent in a Danube inn: "Wagner war ganz Politik; er erwartete von dem Siege der Revolution eine vollständige Wiedergeburt der Kunst, der Gesellschaft, der Religion, ein neues Theater, eine neue Musik." ${ }^{28}$ Upon returning to Dresden, he very soon got the opportunity to meet Mikhail Bakunin, whom he had read about, admired and from whom he obviously could learn something about regeneration..$^{29}$ After all,

${ }_{25}$ Richard Wagner, “The Revolution”, in: Richard Wagner's Prose Works, Vol. VIII. Posthumous, Etc., trans. William Ashton Ellis, Kegan Paul, Trench, Trübner and Co., London, 1899, 232.

26 Ibid., 235.

27 Rose, Wagner, Race, and Revolution, page 2 and onwards.

28 "Wagner became all politics; he expected the victory of revolution to completely regenerate art, society, religion, new theatre, new music." Quoted after Martin Gregor-Dellin, Richard Wagner. Sein Leben - sein Werk - sein Jahrhundert: Erster Teil: 1821-1849, in: Richard Wagner, Sämtliche Schriften und Dichtungen, 50250.

29 At that time Bakunin published the influential "Appeal to the Slavs" ("Aufruf an die Slaven", 1848), where he presented his vision of a regenerated, federative and republican Europe. "Thus, dissolution, overturn, and regeneration in the entire North and East of Europe, a free Italy, and as the last result, the Universal Federation of European Republics". Mikhail Bakunin, “Appeal to the Slavs (1848)", in: Sam Dolgoff (ed.), Bakunin on Anarchy. Selected 
years later, in the autobiography My Life (Mein Leben, 1865-1880), Wagner himself showed that he had been well-acquainted with Bakunin's advocacy of regeneration. Among other things, he wrote that Bakunin was the intellectual offspring of Rousseau's and Hegel's philosophy and that, by way of France and Germany, he "wandered back [...] to the borders of the Slavic world, from which he expected the regeneration of the world to begin on the grounds that the Slavs had been least corrupted by civilization". ${ }^{30}$

Mikhail Bakunin first came to Dresden in 1842. On that occasion, he collaborated with Arnold Ruge, a Left-Hegelian who was the editor of Deutsche Jahrbücher für Wissenschaft und Kunst (under the pen name Jules Elysard, Bakunin published an article "The Reaction in Germany" ["Die Reaktion in Deutschland", 1842] in this journal). Until 1843 (when it was moved to Paris and renamed Deutsch-Französischer Jahrbücher), the journal was an important organ of radical democrats in Germany. The contributors interpreted new democratic ideas as a prolongation of the tradition of the Prussian Wars of Liberation, which were referred to, as Ruge put it, as a movement dedicated to the regeneration of Prussia and the uprising of all the people against Napoleon. ${ }^{31}$ Indeed, the understanding of regeneration in the 'French way' became relevant in Germany only during the Anti-Napoleonic Wars of Liberation (1813-1815). ${ }^{32}$ After the Congress of Vienna (1815), it was being increasingly referred to by those who advocated democracy. The German youth movement, exalted by early nationalist sentiments, detached regeneration (or, in keeping with the linguistic purism of the time, Wiedergeburt) from the French sources and radicalized it by making a very peculiar connection with 'the authentically German' legacy of Luther's Reformation. Thus, for example, on $18^{\text {th }}$ October 1817 , under the black-red-golden flag in Wartburg, the students and professors of the University in Jena had "doppeltes Fest der Wiedergeburt des freien Gedankens [in der Reformation] und der Befreiung des Vaterlandes [von Napoleon]". ${ }^{33}$

Works by the Activist-Founder of World Anarchism, trans. Sam Dolgoff, Vintage Books, New York, 1972, 67.

${ }^{30}$ Richard Wagner, My Life, Cambridge University Press, Cambridge, 1983, 385-386.

${ }^{31}$ Cf. Werner Conze, "Reform, Reformation", in: Otto Brunner, Werner Conze and Reinhart Koselleck (eds.), Geschichtliche Grundbegriffe. Vol. 5, Klett-Cotta, Stuttgart, 1997, 884.

32 The notion of regeneration in politics first came into use in Prussia - in the very unpretentious meaning of the reorganization of administration and reform of a social system. Werner Wolgast, "Demokratie", in: Ibid., Vol. 1, 345. Philosophers of that time, such as Fichte, used the German word Umschaffung (transformation) instead. Cf. Andrew Fiala, "Fichte and the Ursprache", in: Daniel Breazeale and Tom Rockmore (eds.), After Jena: New Essays on Fichte's Later Philosophy, Northwestern University Press, Evanston, 2008, 183.

33 "[A] double celebration of regeneration of free thought [in Reformation] and liberation of the fatherland [from Napoleon]". Gregor-Dellin, Richard Wagner, 49896. 
Ruge and his collaborators (such as Bakunin) tried to take advantage of this 'Young-German doctrine' of regeneration by attempting to divert it from the Reformation towards modern democracy and, eventually, republicanism and revolution. In the text "How do republican aspirations stand in relation to the monarchy?" Wagner tied in precisely with this tradition, which was meanwhile further radicalized by the revolution in 1848 and the awakened French republicanism.

Five years after Wagner's death, Friedrich Nietzsche in The Case of Wagner (Der Fall Wagner, 1888) wrote: "Half his lifetime Wagner believed in the Revolution as only a Frenchman could have believed in it." ${ }^{34}$ Nietzsche here definitely referred to the latter half of Wagner's life (1848-1883), when he became publicly known for his conservatism and nationalism. Nietzsche's statement implies that Wagner in 1848 had already acquired the typical French 'faith' in revolution, which, in spite of his subsequent nationalist rhetoric, he never renounced. Although malicious and simplified, Nietzsche's observation has a grain of truth in it. In 1848 Wagner indeed became devoted to a 'faith' that originated in France. But that was not 'faith' in revolution, as Nietzsche thought, but - in regeneration.

However, Wagner in 1848 did not acquire only the French 'faith' in regeneration, but also the German one, which had emerged in the meantime. None of them was only revolutionary. Typical of the French school of thought on regeneration was the dilemma whether regeneration begins by a revolution or after (the failure of) a revolution. The German tradition was marked by the quandary of whether a (long since initiated) regeneration ends with a revolution or whether it should keep thriving, completely indifferent to it. Thus, in $19^{\text {th }}$ century France the dilemma about the relationship between regeneration and revolution remained topical, since it was revived in 1851 (when Napoleon III brought down the Second Republic) and 1870 (when the military defeat against Prussia overthrew the Second Empire), whereas in Germany the increasingly conservative majority in the ranks of German intelligence degraded revolution to a disruptive factor of regeneration as early as in 1849 . Wagner would start to adopt this precise viewpoint after 1849 .

\section{III}

Until May 1849, Wagner wrote about revolution both as a deity that rejuvenated the world and as a destructive force that destroyed "the order of things"

${ }^{34}$ Friedrich Nietzsche, "The Case Of Wagner", in: The Case Of Wagner, Nietzsche Contra Wagner, and Selected Aphorisms, trans. Anthony M. Ludovici, T. N. Foulis, Edinburgh and London, 1911, 9. 
in order to make room for a new, emancipated human race. After fleeing Dresden on $9^{\text {th }}$ May 1849 , he remained an advocate of revolution, but he started perceiving it in a slightly different way and stopped identifying himself as a revolutionary. He changed his opinion on his own role in the revolutionary turmoil because, disillusioned by the crushing of the May Uprising in Dresden, he realized (thus approaching even closer to Bakunin ${ }^{35}$ ) that revolution must be a purely destructive force, not a revitalizing one. In the letter to his wife Minna, which he wrote only five days after leaving Dresden, he claimed that he belonged to the kind of men "nicht das Zerstören reizt uns, sondern das Neugestalten" ["who are not attracted to destruction, but to redesign"], and therefore he concluded:"So scheide ich mich von der Revolution" ["I am detaching myself from the Revolution"]. ${ }^{36}$

In the same state of a disappointed revolutionary who nevertheless still "believed in the Revolution, and in its unrestrainable necessity", Wagner in Paris wrote the paper Art and Revolution, aiming to present the "way of rescue" to the public. As the paper shows, not for a moment did he doubt that someday a successful revolution would be initiated, one that would leave behind ruins that would engulf the whole world. However, he personally lost the ambition to deal with the "political ordering" which "should grow from the ruins of a shamfilled world". His new task was to describe an "Art-work which should rise from the ruins of a sham-bred Art". Therefore he conceived Art and Revolution as a "prophetic mirror", in which art reflected the future of life, ${ }^{37}$ i.e. life's way of surviving the moment of it being swallowed up in ruins. In the light of "the last convulsions", which "so mortally [affect] the artistic efforts of the day", 38 although they did not finish it off, Wagner wanted to dissuade artists from counterrevolutionary views and to show them that they can create artworks with a regenerative potential. In 1848 Wagner invoked revolution and failed miserably. The following year, he wanted to put his art (and all other 'true' art) on the track of regeneration. As he came to realize, revolution was, after all, incapable of rejuvenating the world, like a deity; he started believing that regeneration could do it if it adhered to 'true' art (as a radical opposition to the "lying world").

${ }^{35}$ Cf. Wagner, My Life, 386.

${ }^{36}$ In the same letter he predicted that what lay ahead would be "einer nichtswürdigen $\mathrm{Zu}$ kunft Deutschlands für vielleicht längere Jahre" ["a worthless future of Germany for possibly a long time"], and that the revolutionaries will "aus der tiefsten Hefe des Volkes entstehen" ["arise from the lowest dregs of the people"]. Richard Wagner, "Brief an Minna Wagner, den 14ten Mai 1849”, in: Richard Wagner, Sämtliche Schriften und Dichtungen, 8892-8893.

37 Richard Wagner, "Introduction to Art and Revolution”, in: Richard Wagner's Prose Works. Vol. I, 24.

38 Wagner, “Art and Revolution", 30. 
For that reason, Wagner in Art and Revolution for the first time immediately, permanently and unbreakably linked regeneration to art, and not to art as such, but to the synergy of arts that emerged from the "tragedy", as a "great unified Art-work of Greece [das große griechische Gesamtkunstwerk]", and which had begun to regenerate individually in the meantime. ${ }^{39}$ In 1849 Wagner, who previously showed no signs of religiousness, began to find his "personal creed" in art that was consistently sacralised ${ }^{40}$ on the model of Antiquity. ${ }^{41}$ The basic dogma of this sacralised art was that every nation possessed a "spirit", i.e. a "being", and that cognition of this "being" leads to the regeneration of the entire nation; the most reliable guide to the "essence of the folk", as Wagner believed, was art, which needed to regenerate first to be able to become the guide. The modern European nations - the Germans first of all - could have learned that lesson from the Greeks - the Athenians, first of all. Indeed, at the most important point in Art and Revolution Wagner included Aeschylus's tragedies into his emerging doctrine of regeneration, tragedies that 'honestly' taught the Athenians, gathered in the Theatre of Dionysus during the Dionysia, about what people they belonged to, spreading social harmony among them. In Wagner's opinion, what each Athenian felt was that "all impulses of his fair body, and of his restless soul, urged him to the new birth [Wiedergeburt] of his own being [seines eigenen Wesens] through the ideal expression of art". ${ }^{42}$

In the following years, even decades, Wagner basically continued to recognize the place of birth or Western art in Aeschylus's work, and the place of its rebirth in his own oeuvre. He stylized himself into a modern German Aeschylus and undertook a task that he would tenaciously, for decades, strive to fulfill: to find the artistic definition/expression of the German essence as the necessary condition for embarking on the process of the regeneration of a faltering Germany, and subsequently of all human society.

Translated by Goran Kapetanović

\footnotetext{
39 Ibid., 52.

${ }^{40}$ Roger Hollinrake, "Religious Beliefs", in: Barry Millington (ed.), The Wagner Compendium. A Guide to Wagner's Life and Music, Thames and Hudson, London, 1992, 146.

${ }^{41}$ For more on aporias in Wagner's understanding of the art of Antiquity cf. Dragana Jeremić-Molnar and Aleksandar Molnar, Mit, ideologija i misterija u tetralogiji Riharda Vagnera. Prsten Nibelunga i Parsifal [Myth, Ideology and Mystery in the Tetralogy of Richard Wagner's Tetralogy: The Ring of the Nibelung and Parsifal], Zavod za udžbenike i nastavna sredstva, Belgrade, 2004, 27 and onwards; Dragana Jeremić-Molnar, Rihard Vagner: konstruktor ,istinske“ realnosti. Projekat regeneracije kroz Bajrojtske svečanosti [Richard Wagner, Constructor of a "True" Reality: Project of Regeneration through the Bayreuth Festival], Fabrika knjiga, Belgrade, 2007, 312 and onwards.

42 Wagner, "Art and Revolution", 33.
} 